\title{
ПСИХОЛОГІЧНІ ОСОБЛИВОСТІ ПРОФЕСІЙНОГО ВИГОРАННЯ ОСОБИСТОСТІ
}

\author{
Оксана Якимчук \\ кандидат філософських наук, \\ доцент кафедри психосоматики та психологічної реабілітації \\ Національний педагогічний університет імені М.П. Драгоманова \\ 01601, Україна, м. Київ, вул. Пирогова, 9 \\ Yakimchyk1409@gmail.com, https://orcid.org/0000-0002-9729-8389
}

\begin{abstract}
Анотація
У статті наголошується актуальність проблеми зростання професійного вигорання особистості, адже емоційне благополуччя фахівця $є$ одним із визначальних факторів професійного життя. Соціально-політичні та соціально-економічні зміни висувають нові умови праці, що безумовно впливає на психологічний та соматичний стан особистості. Синдром емоційного вигорання є формою професійної хвороби, яка не тільки руйнує професійну діяльність людини, а й спричиняє виникнення психосоматичних захворювань. Найбільша небезпека синдрому професійного вигорання в тому, що розвивається він майже непомітно і якщо ігнорувати його перші ознаки, то задоволеність від професійної діяльності $з$ кожним днем буде зменшуватись, звичні робочі завдання що зазвичай виконувались 3 легкістю стануть складними, досягнені результати будуть знецінюватись, колеги почнуть викликати роздратування, соматичний стан буде погіршуватись з кожним днем, що призведе до втрати працездатності. У статті приділена увага дослідженню нозологічної приналежності синдрому, оскільки не дивлячись на те, що феномен досліджується більше тридцяти років, щодо його походження та приналежності виникає безліч теорій та суперечок. Розглянуто та проаналізовано основні теоретичні моделі синдрому в сучасній та зарубіжній літературі. Охарактеризовано основні причини та симптоми, виділені основні фактори що сприяють його формуванню. Професійне вигорання не залежить лінійно від таких професійних факторів, як стаж, вік і зовнішня результативність професійної діяльності. Синдром професійного вигорання може формуватися не лише в осіб соціально орієнтованих професій, а й у представників інших професійних груп в тих випадках, коли на перше місце виходить високий ступінь відповідальності за виконувану роботу, нерівноемоційна напруга на роботі переважно в системі «людина - людина» та інші фактори. Водночас професійне вигорання особистості це індивідуальний процес, причиною якого є поєднання суб'єктивних та об'єктивних чинників, які залежать не тільки від особистісних якостей людини а і від індивідуальної системи професійного розвитку та соціальних факторів.
\end{abstract}

Ключові слова: професійне вигорання, емоційне вигорання, стрес, професійна діяльність, систематизація моделей.

\section{Вступ}

Однією з найбільш актуальних проблем сьогодення, яку важко переоцінити, є проблема професійного вигорання. Соціально-політичні та соціально-економічні зміни висувають нові умови праці, що безумовно впливає на психологічний та соматичний стан особистості. Синдром професійного вигорання є формою професійної хвороби, яка не тільки руйнує 
професійну діяльність людини, а й спричиняє виникнення різних психосоматичних захворювань (Мозгова, Ханецька \& Якимчук, 2021). Змінились і морально-духовні цінності та потреби людини. В сучасних умовах суспільства підвищуються умови до кваліфікації працівників, продуктивності їх професійної діяльності. Діяльність є дуже важливою для розвитку людини як повноцінного члена суспільства. Будь-яка професійна діяльність накладає психологічний відбиток на особистість людини, видозмінюючи іiі. Такі зміни мають як позитивні, так і негативні наслідки. Позитивним є формування професіонала високого класу, а негативні - це професійне вигорання. Емоційне благополуччя фахівця $є$ одним із визначальних факторів професійного життя, а повноцінне психічне здоров'я - важливою умовою професійної діяльності.

Професійне вигорання є складним багатокомпонентним феноменом і на сьогодні не існує однозначного розуміння його сутності. Розуміння сутності професійного вигорання, його структури та етапів є вкрай суперечливими. Це зумовлено різними підходами до його опису. Кожен акцентує увагу лише на якомусь одному аспекті та зосереджується лише на певній групі чинників й детермінацій.

Проблема професійного вигорання знайшла своє відображення у дослідженнях вітчизняних та зарубіжних вчених, а саме: Г. Діон, Н. Левицька, М. Лейтер, Л. Малець, В. Орел, Т. Форманюк, Х. Дж. Фрейденберг, У. Шуфелі, Г. Сальє, С. Максименко, В. Бойко та iH.

Проблема «вигорання» привертає увагу та є актуальною тому, що являє собою складну психофізіологічну реакцію й включає психологічний, емоційний та фізичний відхід від активності у відповідь на негативні чинники, що провокують «вигорання».

Актуальність дослідження визначається також високою соціальною значимістю проблеми, швидким темпом іï поширення, а також необхідністю проведення нових фундаментальних досліджень у цій галузі. Мета дослідження: теоретично обгрунтувати та емпірично дослідити психологічні особливості професійного вигорання особистості. Завдання дослідження: 1) здійснити теоретичний аналіз підходів вітчизняних і зарубіжних вчених щодо чинників виникнення професійного вигорання особистості; 2) емпірично дослідити психологічні особливості професійного вигорання особливості.

\section{Методи дослідження}

Для дослідження психологічних особливостей професійного вигорання особистості було використано комплекс методів дослідження: теоретичні (аналіз психологічної літератури, систематизація, узагальнення та структурування даних); емпіричні (тестування):

1. Для визначення розвитку компонентів емоційного вигорання було застосовано методику «Діагностіка рівня емоційного вигорання» (В. Бойко);

2. Для виміру рівнів «вигорання» застосовано методики: «Оцінка власного потенціалу «вигорання» (Дж. Гібсон); Синдром «вигорання» в професіях системи «людини - людина» (Г. Нікіфоров).

Отже, наведені методики дослідження вигорання спрямовані на визначення компонентів «емоційного вигорання» та стадій сформованості емоційного вигорання у фахівця.

\section{Результати та дискусії}

Вперше термін «вигорання» був введений до наукового обігу в 1974 р. американським психіатром Г. Фрейденбергером, який визначав емоційне вигорання як хронічну втому, 
депресію і фрустрацію. Згодом цей термін був модифікований у «вигорання персоналу» та «вигорання особистості» (Freudenberger, 1974). Варто зазничити що дослідженням зазначеного феномену займалися здавна, зокрема Аристотель та Демокрит, які досліджували залежність людини та професії.

Необхідно відзначити, що на даний час у вітчизняній та зарубіжній літературі застосовують різні варіанти перекладу англійського терміну «burnout», що в свою чергу спричинило розвиток найрізноманітніших теорій. Не дивлячись на те, що феномен вивчається більше тридцяти років, опубліковано безліч праць на цю тему, єдиного визначення синдрому й дотепер не існує. Дискусійним залишається питання щодо нозологічної приналежності синдрому.

У більш вузькому розумінні термін професійне вигорання розглядається як емоційне виснаження, виникнення і розвиток якого зумовлюється впливом професійних стрес-факторів.

Виділяють такі групи чинників професійного вигорання:

1) організаційні - безпосередньо пов'язані з управлінням і умовами роботи;

2) діяльністні -пов'язані зі змістом та характером діяльності;

3) особистісні - пов'язані з мотиваційними та індивідуально- психологічними особливостями фахівця (Селье, 2002).

Дискусійним залишається питання співвідношення таких понять як «стрес» i «вигорання». Г. Сельє розглядає вигорання як наслідок тривалого робочого стресу. В рамках теорії стресу та загального адаптаційного синдрому професійне вигорання прирівнюється до третьої стадії стресу (виснаження), якій передує стійкий рівень збудження.

Більшість дослідників, які вивчають ці феномени, розділяють цей погляд в тій чи іншій мірі, пов'язуючи феномен професійного вигорання з професійним стресом або дезадаптацією до умов діяльності й визнаючи це провідним фактором професійних ризиків.

Але дана концепція, на жаль, ігнорує той факт, що в рамках однієї й тієї ж діяльності, однакових стрес-факторів та умов у фахівців спостерігається різний рівень успішності, адаптації та емоційного благополуччя. Проблема досліджень, заснованих на теорії стресу не дає можливості вийти за рамки зовнішніх факторів і виявити всі психологічні механізми вигорання. Сучасні дослідження наприклад Н. Жигінас, Ю. Петрова сфокусовані в основному на способах подолання стресу, психологічних особливостях, що сприяють подоланню стресу та рівнях психологічної адаптації.

Найбільш частий синонім професійного вигорання - емоційне вигорання, оскільки багатьма авторами даний синдром розглядається переважно з емоційної точки зору. Дослідники К. Чернісс і В. Бойко визначають синдром вигорання негативним процесом, що розвивається на тлі хронічного стресу й веде до виснаження емоційно-енергетичних ресурсів працюючої людини. Цей підхід характеризується високою термінологічною точністю i психологічною змістовністю, що дозволяє вирішити безліч протиріч. (Бойко, 1999).

Щодо моделей професійного вигорання то більшість сучасних дослідників підтримують трикомпонентну модель емоційного вигорання, запропоновану С. Maslach i S. Jackson, згідно з якою під синдромом вигорання розуміється стан фізичного, емоційного й розумового виснаження, що виявляється в професіях соціальної сфери та включає в себе три основні складові:

- емоційне виснаження (почуття емоційної спустошеності, втоми від роботи, зниження настрою); 
- деперсоналізація (дегуманізація: негативне, цинічне ставлення до колег і до клієнтів, відстороненість);

- редукція професійних досягнень (почуття некомпетентності й усвідомлення власної неспроможності, неуспішності (Maslach \& Jachson, 1981).

Але $є$ й інші моделі професійного вигорання. Чотирьохфакторні моделі пояснюють появу четвертого додаткового фактору специфічністю професійної діяльності. Наприклад, таким фактором може бути тривога фахівців за сім'ю у зв'язку з тривалим перебуванням за межами дому (Журавлева \& Сергиенко, 2011).

Прихильники двофакторної моделі вигорання пропонують різні варіанти його будови. D.E. Green стверджує, що фактори емоційного виснаження і деперсоналізації є частинами, включеними в один базовий фактор, який разом 3 редукцією професійних досягнень i становить структуру вигорання. А. Garden визначає деперсоналізацію як фактор, який $є$ специфічним лише для професій соціального обслуговування. T. Kalliath та інші автори виключають зі структури вигорання редукцію професійних досягнень (Орел, 1999).

Однофакторні моделі трактують вигорання як комплексний стан фізичного, психічного та емоційного виснаження, викликаний тривалим включенням в емоціогенну ситуацію (Pains \& Maslach, 2003).

Стадії розвитку вигорання відповідно до шестифакторної моделі, запропонованої M. Burisch, характеризуються наступним чином:

1. Застережлива фаза. Проявляється в надмірній активності в роботі й витісненням переживань, невдач і розчарувань, відмова від потреб, не пов'язаних з роботою.

2. Зниження рівня власної участі в професійній діяльності, що супроводжується незадоволеністю роботою і приписуванням причин власних невдач іншим.

3. Емоційні реакції. На цій стадії спостерігаються безпідставні страхи, постійне відчуття провини, депресія, зниження самооцінки, агресивність, конфліктність.

4. Фаза деструктивної поведінки. Спостерігається зниження концентрації уваги, ригідність мислення, знижується концентрація уваги, відсутність здатності виконувати складні завдання, байдужість, уникнення неформальних контактів.

5. Психосоматичні реакції й зниження імунітету. Безсоння, головний біль, тахікардія, розлади травлення, залежність від нікотину, кофеїну та алкоголю.

6. Розчарування і негативна життєва установка. На цій стадії з'являється почуття безпорадності, провини, втрата сенсу життя, екзистенціальний відчай (Burisch, 1993).

Greenberg J. пропонує п’ятиступінчасту динамічну модель («медовий місяць», «недолік палива», хронічні симптоми, криза, «пробивання стіни») процесу розвитку вигорання 3 прогресуючим наростання вираженості його проявів, що виявляються в зниженні ентузіазму, втраті продуктивності діяльності, хронічній втомі та пригніченості, незадоволеності якістю життя і гострими соматичними або психологічними порушеннями (Greenberg, 2004).

Згідно досліджень Shirom A. (Shirom, 1989), вигорання характеризується емоційним виснаженням, фізичною й пізнавальною втомою, бо свідчить про виснаження енергетичних ресурсів організму внаслідок хронічної напруги на роботі й в житті. До об'єктивних факторів, що впливають на виникнення професійного вигорання, відносять організаційні та комунікативні особливості професійної діяльності: умови роботи, зміст праці, соціальнопсихологічні чинники. Група організаційних чинників, куди включаються умови матеріального середовища, зміст роботи і соціально-психологічні умови діяльності, грають домінуючу роль у виникненні вигорання (Hakanen, Bakker, Jokisaari \& Markku, 2011). 
Вигорання також розглядається як негативна поведінка в організаціях, адже вигорання впливає не тільки на індивіда, але й на організацію в цілому (Лукьянова, Водопьянова, Орел, Подсадной, Юрьева \& Игумнова, 2008).

Цікавою є концепція контрпереносу, що визнає верховенство емоційного фактору в процесі вигорання, тобто сукупності неусвідомлюваних емоційних реакцій фахівця. Згідно цієї концепції саме невміння вчасно відрефлексувати й емоційно висловити подібні реакції підвищує ризик перенапруження, що веде до розвитку синдрому професійного вигорання.

Симптоми професійного вигорання, умовно можна розділити на кілька груп: 1) психофізичні; 2) соціально-психологічні; 3) поведінкові.

До психофізичних симптомів відносять: 1) синдром хронічної втоми; 2) емоційне та фізичне виснаження; 3) зниження сприйнятливості до змін факторів зовнішнього середовища; 4) астенія; 5) часті безпричинні головні болі або розлади шлунково-кишкового тракту; 6) різка зміна ваги (як зниження, так і підвищення); 7) гіперсонмія або нарколепсія; 8) порушення дихання; 9) зниження сенсорної чутливості.

Серед соціально-психологічних симптомів професійного вигорання виділяються: 1) зниження емоційного тонусу, почуття пригніченості; 2) підвищена дратівливість; 3) спалах невмотивованого гніву, відмова від спілкування; 4) безпричинне переживання негативних емоцій (в тому числі почуття підозрілості, сорому, провини, образи); 5) підвищена тривожність; 6) гіпервідповідальність; 7) загальна негативна установка на життєві й професійні перспективи.

Серед поведінкових симптомів виділяють: 1) невиконання важливих, пріоритетних завдань; затримка на дрібних деталях; 2) почуття марності; 3) зниження ентузіазму по відношенню до роботи; 4) дистанційованість від співробітників і клієнтів (пацієнтів); 5) зловживання алкоголем, наркотиками (Самоукина, 2003).

Для емпіричного дослідження психологічних особливостей професійного вигорання особистості було залучено 35 фахівців різних спеціальностей віком від 27 до 43 років.

За результатами методики «Діагностика рівня емочійного вигорання (В. Бойко) були отримані результати, які зазначені в табл.1.

Таблиия 1

Результати сформованості фаз у відсотках

\begin{tabular}{|l|c|c|c|}
\hline Кількісні показники: & $\begin{array}{c}\text { Фаза } \\
\text { «Напруження» }\end{array}$ & $\begin{array}{c}\text { Фаза } \\
\text { «езистенції» }\end{array}$ & $\begin{array}{c}\text { Фаза } \\
\text { «Виснаження» }\end{array}$ \\
\hline $\begin{array}{l}36 \text { і менше балів - фаза не } \\
\text { сформована }\end{array}$ & $66 \%$ & $72 \%$ & $50 \%$ \\
\hline $\begin{array}{l}37-60 \text { балів - фаза на } \\
\text { стадії формування }\end{array}$ & $28 \%$ & $28 \%$ & $32 \%$ \\
\hline $\begin{array}{l}61 \text { і більше балів - фаза } \\
\text { сформована }\end{array}$ & $6 \%$ & $0 \%$ & $18 \%$ \\
\hline
\end{tabular}

Згідно результатів дослідження можна зробити висновок що, фази напруження та резистенції у переважної більшості респондентів не $\epsilon$ сформованими або починають тільки формуватись.

Щодо фази виснаження, майже в половини опитаних вона знаходиться на стадії формування, а у декількох осіб - сформована. Для цієї фази характерна психофізична 
перевтома, спустошеність, нівелюванням власних професійних досягнень, порушення професійної комунікації.

Звертаючи увагу на окремі симптоми, якими супроводжується кожна фаза, найбільш домінуючими виявились наступні: «загнаність у кут», неадекватне вибіркове емоційне реагування та емоційне відчуження.

За результатами методики Синдром «вигорання» в професіях системи «людина людина» (Г. Нікіфоров) було отримано результати, які зазначені в табл. 2.

Таблиия 2

Рівні вигорання за методикою «Синдром «вигорання» в професіях системи «людина - людина» (Г.С. Нікіфоров) у відсотках

\begin{tabular}{|c|c|c|c|}
\hline \multirow{2}{*}{$\begin{array}{c}\text { Рівні } \\
\text { «вигорання» }\end{array}$} & \multicolumn{3}{|c|}{ Компоненти вигорання } \\
\hline & $\begin{array}{c}\text { Емочійне } \\
\text { виснаження }\end{array}$ & Деперсоналізаиія & $\begin{array}{c}\text { Редукиія особистих } \\
\text { досягнень }\end{array}$ \\
\hline Низький & $72 \%$ & $50 \%$ & $66 \%$ \\
\hline Середній & $18 \%$ & $40 \%$ & $34 \%$ \\
\hline Високий & $10 \%$ & $10 \%$ & $0 \%$ \\
\hline
\end{tabular}

За результатами методики було виявлено, що у переважної більшості працівників показник «вигорання» знаходиться на низькому рівні, за винятком декількох респондентів, результати яких показали високий рівень «вигорання» по таким субшкалам: емоційне виснаження (10\%) та деперсоналізація (10\%). Емоційне виснаження в свою чергу характеризується заниженим емоційним фоном та байдужістю або емоційним перенасиченням.

Деперсоналізація вказує на деформацію стосунків між людьми. Це може проявлятися через зростання залежності від інших людей або ж зростання негативізму.

Методика «Оцінка власного потенціалу «вигорання» (Дж. Гібсон) дозволила отримати результати, які зазначені в табл.3.

Таблиия 3

Рівні вигорання за методикою «Оцінка власного потенціалу «вигорання» (Дж. Гібсон) у відсотках

\begin{tabular}{|l|c|c|c|}
\hline \multirow{2}{*}{$\begin{array}{c}\text { «вівні } \\
\text { «виграння» }\end{array}$} & \multicolumn{3}{|c|}{ Компоненти вигорання } \\
\cline { 2 - 4 } & Деперсоалізація & $\begin{array}{c}\text { Особиста } \\
\text { задоволеність }\end{array}$ & Емочійне виснаження \\
\hline Низький & $60 \%$ & $10 \%$ & $60 \%$ \\
\hline Середній & $32 \%$ & $72 \%$ & $32 \%$ \\
\hline Високий & $8 \%$ & $18 \%$ & $8 \%$ \\
\hline
\end{tabular}

Проаналізувавши та порівнявши отримані результати за останніми двома методиками, можна зазначити, що вони майже збігаються за компонентами деперсоналізації та емоційного виснаження, особливо на низькому та високому рівнях.

Особиста задоволеність опитуваних знаходиться переважно на середньому рівні (72\%), лише 10\% мають низький рівень особистої задоволеності, решта - високий (18\%).

Підсумовуючи все вищезазначене, можна зробити наступні висновки та узагальнення. За допомогою даних методик вдалося визначити наступні провідні ознаки та психологічні 
особливості професійного вигорання особистості: відчуття емоційної напруженості, почуття спустошеності, незадоволеність життям та загальне погіршення фізичного стану здоров'я, зниження мотивації до професійної діяльності.

\section{Висновки}

Аналіз психологічної літератури вітчизняних і зарубіжних дослідників свідчить про те, що професійне вигорання $\epsilon$ складним багатокомпонентним феноменом i на сьогодні залишається дискусійним питання щодо нозологічної приналежності зазначеного феномену. Найбільш широке розповсюдження отримала тьохфакторна модель запропонована C. Maslach i S. Jackson, згідно з якою під синдромом вигорання розуміється стан фізичного, емоційного й розумового виснаження.

Можна також відокремити наступні аспекти дослідження означеної проблематики: вивчення та обгрунтування сутності та структури емоційного вигорання (Л. Дика, Л. Карамушка, Є. Картава, M. Burish, C. Maslach, B. Perlman та ін.), визначення особливостей емоційного вигорання в різних професійних групах (О. Богучарова, О. Грейліх, Ю. Жогно, Н. Чепелєва та ін.), аналіз детермінант виникнення та розвитку емоційного вигорання (Т. Большакова, М. Борисова, P. Costa, S. Hobfoll, W. Schaufeli та ін.), розробка відповідного психодіагностичного інструментарію (В. Бойко, Н. Водоп'янова, О. Рукавішников, M. Штейн, S. Jackson, C. Maslach та ін.), розробка та впровадження методів психокорекції, спрямованих на попередження та подолання емоційного вигорання (О. Бабич, В. Байдик, Н. Водоп'янова, Н. Гончарук, Н. Грисенко, Т. Титаренко, Т. Яценко та ін.).

Професійне вигорання не залежить лінійно від таких професійних факторів, як стаж, вік і зовнішня результативність професійної діяльності. Також, синдром може формуватися не лише в осіб соціально орієнтованих професій, а й у представників інших професійних груп в тих випадках, коли на перше місце виходить високий ступінь відповідальності за виконувану роботу. Вигорання розвивається також у осіб, що зазнають нерівноемоційної напруги на роботі, переважно в системі «людина - людина» і не мають можливості іiі адекватно компенсувати. Постійна напруга та стрес - також $є$ передумововами професійного вигорання. Водночас професійне вигорання - це індивідуальний процес, причинами якого є поєднання суб'єктивних та об'єктивних чинників, які залежать не тільки від особистісних якостей людини а і від індивідуальної системи професійного розвитку та соціальних факторів.

Наведені результати емпіричного дослідження свідчать, що майже у половини досліджуваних фаза виснаження знаходиться на фазі формування, а в деяких осіб сформована. Домінуючими є наступні симптоми: «загнаність у кут», неадекватне вибіркове емоційне реагування та емоційне відчуження. За методикою діагностики синдрому «вигорання» в професіях системи «людина - людина» у 10\% респондентів було виявлено високий рівень «вигорання» за шкалами емоційне виснаження та деперсоналізація. Майже подібні результати за цими шкалами були отримані за методикою діагностики оцінки власного потенціалу «вигорання» (Дж. Гібсон). Емоційне виснаження в свою чергу характеризується зниженням емоційного фону, байдужістю або емоційним перенасиченням.

За допомогою використаних методик вдалося визначити наступні провідні ознаки та психологічні особливості професійного вигорання особистості: відчуття емоційної напруженості, почуття спустошеності, незадоволеність життям та загальне погіршення фізичного стану здоров'я, зниження мотивації до професійної діяльності. 
3 огляду на вищезазначене, перспективою подальшого дослідження є розробка та апробація комплексної програми психокорекції та профілактики професійного вигорання, а також у подальшій перспективі дослідження вбачається необхідність вивчення питання розвитку вигорання при виникненні нових професій з метою професійного самозбереження фахівця та подолання негативних тенденцій професійного вигорання.

\section{Література}

1. Бойко, В.В. (1999). Синдром «эмоичонального выгорания» в профессиональном общении. Санкт-Петербург : Питер.

2. Водопьянова, Н.Е. (2009). Психодиагностика стресса. Санкт-Петербург : Питер.

3. Гринберг, Дж. (2004). Управление стрессом. Санкт-Петербург : Питер.

4. Журавлева, Е.А., \& Сергиенко, А.Л. (2011). Стресс, выгорание, совладание в современном контексте. Москва : Изд-во «Ин-т психологии РАН».

5. Лукьянова, В.В., Водопьянова, Н.Е., Орел, В.Е., Подсадной, С.А., Юрьева, Л.Н., \& Игумнова, С.А (2008). Современные проблемы исследования синдрома выгорания у специалистов коммуникативных профессий. (Монография). Курск : Изд-во «Курский государственный университет».

6. Мозгова, Г.П., Ханецька, Т.I., \& Якимчук, О.І. (2021). Психосоматика: психічне, тілесне, соиіальне. Хрестоматія: Навчальний посібник. Київ : НПУ імені М.П.Драгоманова.

7. Орел, В.Е. (1999). Исследование феномена «психического выгорания» в отечественной и зарубежной психологии. Проблемы общей и организаџионной психологии, 76-97.

8. Селье, Г. (2002). Стресс без дистресса. Москва : Прогресс.

9. Самоукина, Н.В. (2003). Психология профессиональной деятельности. Санкт-Петербург : Питер.

10. Burisch, M., Schaufeli, W.B., Maslach, C., \& Marek, T. (1993). In search of theory: Some ruminations on the nature and etiology of burnout. Professional burnout: Recent developments in theory and research (pp. 75-93). New York : Taylor \& Francis.

11. Enzmann, D., Berief, P., Engelkamp, C. et al. (1992). Burnout and coping will burnout. Development and evaluation of a burnout workshop. Berlin : Technische Univercitat Berlin, Institut fur Psychologie.

12. Freundberger, H.J. (1974). Staff burnout. Social Scienes, 30(1), 159-165. https://doi.org/10.1111/j.1540-4560.1974.tb00706.x

13. Hakanen, J., Bakker, A., Jokisaari, B., \& Markku, A (2011). 35-year follow-up study on burnout among Finnish employees. Journal of Occupational Health Psychology, 16(3), 345-360.

14. Maslach, C., \& Jachson, S.E. (1981). The measurement of experienced burnout. Journal of Occupational Behaviour, 2, 99-113.

15. Pains, A., \& Maslach, C. (2003). Praktikum po sotsial'noi psikhologii [Experiencing social psychology]. Saint Petersburg : Piter, 528 p. (In Russ.).

16. Storlie, F. (1979). Burnout: the elaboration of a concept. AJN Am J Nursing, 2108-2111.

17. Shirom, A. (1989). Burnout in Work Organizations. In C.L. Cooper, \& I. Robertson (Eds.), International Review of Industrial and Organizational Psychology (pp. 25-48). New York : Wiley.

\section{References}

1. Boyko, V.V (1999). Sindrom "emotsionalnogo vyigoraniya" v professionalnom obschenii [Syndrome of "emotional burnout" in professional communication]. Saint Petersburg : Piter [in Russian]. 
2. Vodopyanova, N.E (2009). Psihodiagnostika stressa [Psychodiagnostics of stress]. Saint Petersburg : Piter [in Russian].

3. Greenberg, J. (2004). Upravlenie stressom [Stress management]. Saint Petersburg : Piter [in Russian].

4. Zhuravleva, E.A., \& Sergienko, A.L (2011). Stress, vyigoranie, sovladanie v sovremennom kontekste [Stress, burnout, coping in a modern context]. Moscow : Publishing House of the Institute of Psychology of the Russian Academy of Sciences [in Russian].

5. Lukyanova, V.V, Vodopyanova, N.E, Orel, V.E, Podsadnoy, S.A, Yurieva, L.N, \& Igumnova, S.A (2008). Sovremennyie problemyi issledovaniya sindroma vyigoraniya $u$ spetsialistov kommunikativnyih professiy [Modern problems of burnout syndrome research in specialists of communicative professions]. Kursk : Publishing house "Kursk State University" [in Russian].

6. Mozgova, G.P., Khanetska, T.I., \& Yakymchuk, O.I. (2021). Psihosomatika: psihichne, tilesne, social'ne. Hrestomatiya: Navchalnyy posibnyk [Psychosomatics: psycho, solid, social. Reader: Textbook]. Kyiv : NPU imeni M.P. Dragomanova [in Ukrainian].

7. Orel, V.E. (1999). Issledovanie fenomena "psihicheskogo vyigoraniya" v otechestvennoy i zarubezhnoy psihologii [Research of the phenomenon of "mental burnout" in domestic and foreign psychology]. Problemy obschey i organizatsionnoy psihologii-Problems of general and organizational psychology, 76-97 [in Russian].

8. Selye, G. (2002). Stress bez distressa [Stress without distress]. Moscow : Progress [in Russian].

9. Samoukina, N.V. (2003). Psihologiya professionalnoy deyatelnosti [Psychology of professional activity]. Saint-Petersburg : Piter [in Russian].

10. Burisch, M., Schaufeli, W.B., Maslach, C., \& Marek, T. (1993). In search of theory: Some ruminations on the nature and etiology of burnout. Professional burnout: Recent developments in theory and research (pp. 75-93). New York : Taylor \& Francis.

11. Enzmann, D., Berief, P., Engelkamp, C. et al. (1992). Burnout and coping will burnout. Development and evaluation of a burnout workshop. Berlin : Technische Univercitat Berlin, Institut fur Psychologie.

12. Freundberger, H.J. (1974). Staff burnout. Social Scienes, 30(1), 159-165. https://doi.org/10.1111/j.1540-4560.1974.tb00706.x

13. Hakanen, J., Bakker, A., Jokisaari, B., \& Markku, A (2011). 35-year follow-up study on burnout among Finnish employees. Journal of Occupational Health Psychology, 16(3), 345-360.

14. Maslach, C., \& Jachson, S.E. (1981). The measurement of experienced burnout. Journal of Occupational Behaviour, 2, 99-113.

15. Pains, A., \& Maslach, C. (2003). Praktikum po sotsial'noi psikhologii [Experiencing social psychology]. Saint Petersburg : Piter, 528 p. (In Russ.).

16. Storlie, F. (1979). Burnout: the elaboration of a concept. AJN Am J Nursing, 2108-2111.

17. Shirom, A. (1989). Burnout in Work Organizations. In C.L. Cooper, \& I. Robertson (Eds.), International Review of Industrial and Organizational Psychology (pp. 25-48). New York : Wiley. 


\title{
PSYCHOLOGICAL PECULARITIES OF PROFESSIONAL BURNOUT \\ Oksana Yakymchuk \\ Ph.D in Philosophy, Associate Professor \\ of the Department of Psychosomatics and Psychological Rehabilitation \\ National Pedagogical Dragomanov University \\ 9, Pyrohov Str., Kyiv, Ukraine, 01601 \\ Yakimchyk1409@gmail.com, https://orcid.org/0000-0002-9729-8389
}

\begin{abstract}
The article emphasizes the urgency of the problem of professional burnout growth, because the emotional well-being of the specialist is one of the determining factors of professional life. Sociopolitical and socio-economic changes promote new working conditions that certainly affect the psychological and somatic state of the individual. Emotional burnout syndrome is a form of occupational disease that not only destroys a person's professional activity, but also causes psychosomatic illnesses. The greatest danger of burnout is that it develops almost imperceptibly and if you ignore its first signs, the satisfaction with professional activities will decrease with each passing day, the usual work tasks that are usually performed will easily become difficult, the results will be devalued, colleagues will cause irritation, somatic condition will worsen with each passing day, which leads to disability. The article focuses on the study of the nosological affiliation of the syndrome, because despite the fact that the phenomenon has been studied for more than thirty years, there are many theories and controversies about its origin and affiliation. The main theoretical models of the syndrome in modern and foreign literature are considered and analyzed. The main causes and symptoms are described, the main factors contributing to its formation are identified. Burnout does not depend linearly on such professional factors as seniority, age and external performance. Burnout syndrome can be formed not only in socially oriented professions, but also in representatives of other professional groups in cases where the first priority is a high degree of responsibility for the work performed, unequal emotional stress at work, mainly in the "man - man" system and other factors. At the same time, professional burnout is an individual process caused by a combination of subjective and objective factors that depend not only on personal qualities but also on the individual system of professional development and social factors.
\end{abstract}

Keywords: professional burnout, emotional burnout, stress, professional activity, systematization of models.

Подано 06.09.2021

Рекомендовано до друку 02.11.2021 